Journal of Humanities, Social and Management Sciences (JHSMS)

eISSN: 2788-4791 (online)

https:// doi.org/10.47264/idea.jhsms/2.2.22

Vol. 2, No. 2 (July-December 2021), 302-317

https://www.ideapublishers.org/index.php/jhsms

Research Article

\title{
Exploring the discourse of National Islam and Foreign Islam in the Australian press: A critical discourse analysis
}

\author{
Muhammad Junaid Ghauri*1 ${ }^{1}$ Amrat Haq $^{1}$ | Riffat Alam ${ }^{2}$
}

1. Department of Media \& Communication Studies, International Islamic University Islamabad, Pakistan.

2. Department of Mass Communication, Karakoram International University, Gilgit-Baltistan, Pakistan.

*Corresponding Author Emails: muhammad.junaid@iiiu.edu.pk|mjghauri84@gmail.com

Received: September 14, 2021

Published: December 31, 2021

\begin{abstract}
Research conducted in some European countries and in the US has evidenced that there is a considerable difference in the media coverage of the National/Internal and Foreign/External Islam. Wherein, the latter is viewed and portrayed as a 'greater threat' to the mainstream society. This research endeavour is an effort to explore the predominant themes associated with the Foreign/External Islam in the editorials of the two selected Australian newspapers during January 1, 2016 to March 31, 2017. The researcher has employed Tuen A. van Dijk's (1998) ideological square and lexicalization strategies from the Critical Discourse Analysis (CDA) paradigm to examine the editorials of The Age and The Australian. The research findings are evident that in the coverage of the Foreign Islam both the selected newspapers have associated 'conflict', 'violence' and 'collectivism' with Islam and Muslims, however The Australian highlighted 'women underrepresentation' also. While covering the National Islam, The Age highlighted the 'victimization' and 'prejudice' to Muslims in Australia and stressed on the need of 'understanding', 'harmony' and 'cohesion'. However, in The Australian the National Islam also received the same treatment as did the Foreign Islam in terms of themes.
\end{abstract}

Keywords: National Islam, Foreign Islam, critical discourse analysis, ideological square, lexicalization, representation.

\section{How to Cite:}

Ghauri, M. J., Haq, A., \& Alam, R. (2021). Exploring the discourse of National Islam and Foreign Islam in the Australian press: A critical discourse analysis. Journal of Humanities, Social and Management Sciences (JHSMS), 2(2), 302-317. https://doi.org/10.47264/idea.jhsms/2.2.22

Publisher's Note: IDEA PUBLISHERS (IDEA Publications Group) stands neutral regarding jurisdictional claims in the published maps and institutional affiliations.

Copyright: @ 2021 The Author(s), published by IDEA PUBLISHERS (IDEA Publications Group).

Licensing: This is an Open Access article published under the Creative Commons AttributionNonCommercial 4.0 International License (http://creativecommons.org/licenses/by-nc/4.0/) 


\section{Introduction}

While Islam has predominant space in international reporting, termed as External and/or Foreign Islam by researchers, it is also a religion followed by a significantly large 'minority' in the West. The researchers term it as the Internal and/or National Islam (Mertens, Representation of Islam in the News: a cross cultural analysis). The relationship between the Muslim minority and the 'main-stream' societies in the Europe, termed as 'essential European cultural problem', is problematic (Modood et al., 2006). Findings of some latest research carried out in various European countries have identified a considerable variation and contrast in the coverage of Islam and Muslims within and outside the boundaries of the native country. The findings are evident that the Muslims outside a given country (Foreign/External Islam) are reported in an entirely different terms by the local media as compared to the Muslims within the boundaries of that country (National/Internal Islam). Wherein, the former i.e., the Foreign/External Islam has been perceived and projected in terms of a 'greater threat' (Mertens, 2016 p.61; Ibrahim, 2010; d'Haenens and Bink, 2007).

The international news coverage has deliberately excluded or has played down the vital sociocultural and economic contributions of the Muslims in the European mainstream society (Mertens, 2016 p.60). Where National/Internal Islam is less conflated with the violence, the Foreign/External Islam is labelled more with the themes of conflict, violence, female underrepresentation, and collectivization (Mertens, 2016 p.28, 73; Ibrahim, 2010). In Netherlands the news media coverage of Islam is overwhelmed with the themes of 'foreign threat' and 'domestic other' (Van Drunen, 2013).

The 'female underrepresentation' is another individual Muslim actor which includes negative and stereotypical construction of Islam and Muslims. Depiction of Muslim females being oppressed, subjugated and discriminated due to the Islamic value and social system and by the Muslim men constructs a distorted and vilified image of Islam and Muslims (Richardson, 2004 p. 89, cited in Mertens, 2016. p. 62). The 'collectivization' approach generalizes all Muslims regardless of their distinguishing and distinctive individual, geographical, social and cultural identities. Using this strategy, the international news media associate 'militancy', 'extremism' and 'terrorism' with the 'Islamic' instead of highlighting the individual identity of the person (Muslim) who follows Islam (Baker et al., 2013, p. 255, cited in Mertens, 2016, p. 62).

The coverage patterns in the editorial contents of the Australian newspapers related to Islam and Muslims within the Australian boundaries (National) is significantly different from that of living outside the Australian boundaries (Foreign). The coverage of Islam and Muslims outside the Australian boundaries (Foreign Islam) is overwhelmed with the themes of violence, conflict and terrorism (Ghauri \& Umber, 2019).

This study is set to explore and to investigate whether and to what extent the 'Foreign Islam' has been projected as 'greater threat' by the selected Australian newspapers. The researchers has attempted to explore and identify the predominant themes that have been associated with the 'Foreign Islam' and with the 'National Islam'. The findings of this study would help to map out the themetic differences between the 'Foreign Islam' and the 'National Islam' within in the editorial contents of the The Age and The Australian during January 1, 2016 to March 31, 2017. Therefore, the study is mainly focused on a key research question i.e. What have been the predominant themes regarding 'Foreign/External Islam' and 'National/Internal Islam' in the 
Exploring the discourse of National Islam and Foreign Islam in the Australian press ...

coverage of Islam and Muslims by the selected Australian newspapers during the time period under study?

\section{1. 'National Islam' and 'Foreign Islam'}

Editorial contents are considered as Foreign/External Islam discourse which cover and comment on Islam and Muslims outside the national boundaries of Australia. One the other hand, the editorial contents are considered as the National/Internal Islam that cover and highlight the matters concerning Islam and Muslims within the national boundaries of Australia. The researcher has employed the lenses of 'lexicalization' and 'ideological square' to explore and identify the predominant themes related to 'Foreign Islam' and 'National Islam' within the editorial contents of The Age and The Australian.

\section{Literature review}

This research endeavor aims to study the Australian media in the context of the Muslims' representation as Australia is known to be a migrant friendly state (Alharbi, 2017) and for years Muslim population has been provided with all possible facilities and advantages with no prejudice. Australia's Muslim community is as diverse as that of many other countries in Europe and other parts of the world. According to a media release from the Australian Bureau of Statistics (ABC) on June 27, 2017, Islam has overtaken Buddhism as the second most popular Australian religion, with 2.6 percent of the residents, after Christianity (52 percent) (Anon., 2016). According to the recent figures, the Muslim population in Australia has expanded by 77 percent during past decade, from 300,000 in 2006 ( 2 percent) to over 604,000 (2.6 percent) (Tolj, 2017). They hail from more than 120 different nations throughout the world, with the majority being from Lebanon and Turkey. Muslims from Asian countries including Bangladesh, India, Indonesia, Malaysia, Pakistan, and from Arab nations, as well as America and Europe, make up a substantial Muslim community. In Australia, converts constitute a relatively smaller fraction of the whole populace. Muslims come to Australia for a number of reasons, including to join their families, to flee war and strife in their native countries, to pursue job and promotion, and so on (Anon, 2007).

For a long time, the Australian Muslim community has relished religious freedom by practicing their faith and having their own schools and associations. Nonetheless, a significant research findings have evidenced a considerable negative representation of the Muslim communities which have made them vulnerable to racist incidents, marginalization, intimidation, and prejudice, particularly since Brussels shootings, Madrid bombings, Bali attacks, 7/7, and 9/11 among other events (Alharbi, 2017; Safi \& Evershed, 2015; Quayle \& Sonn, 2009; Rane, 2008; Rane, 2000; Yasmeen, 2007; Munro, 2006; Akbarzadeh \& Smith, 2005; Susskind, 2002). Therefore, this study aims to explore and map out current developments in the depiction of Islam and Muslims within and outside the Australian borders i.e., the National/Internal Islam and the Foreign/External Islam, respectively, in The Age and The Australian from January 1, 2016 to March 31, 2017. The researcher believes that identifying and exploring recent themes linked with the 'Foreign Islam' and with the 'National Islam' in the Australian newspapers' editorial treatment and construction of Islam and Muslims will be a helpful contribution to the existing literature.

The clash between Islam and the West has a long history. For a long time, the West has despised 
Islam and Muslims (Nurullah, 2010). Muslims have been 'historicized' rather than comprehended as a result of the connection of Muslim-identified entities in some violent and terrorist activities throughout the world. Any violent or terrorist incident is automatically and conveniently linked to Islam and Muslims by the international media, based on pre-set prejudices or stereotypes developed in a certain way (Nurullah, 2010).

Islam and the Western world's terms and relations have remained tense for many years before the 9/11 attacks in America, even though some academics do not approve the concept of linking Islam to a geographic entity i.e., the West. Since the 1979 Iranian Revolution and the 1991 Gulf War, Islam and Muslims have gotten a significant attention from the Western media, which has depicted them in stereotypically unfriendly, negative, hostile and traumatic ways (Rane, 2008; Said, 1997). Furthermore, following the 9/11 attacks the image, construction and the portrayal of Islam and Muslims in this form of media has deteriorated. A considerable number of research findings have evidenced that the media's portrayal of Islam and Muslims has been biased and derogatory during all those times (Rane, 2008). Because the media has a propensity to focus on the 'unique' and dramatic, a comparatively larger part of the media treatment and coverage of Islam and Muslims has focused on negative situations such as extremist and violent activities. As a result, many who rely only on the news media for information see Islam and Muslims as pictured by the news media. People are bound to have a mediated image of Islam and Muslims in Western nations like Australia, where wider society cannot have direct interaction with Muslims because the Muslims are in smaller number. So, it is the media that have familiarized them with the Islam and Muslims (Said, 1997).

Elisabeth Poole (2016) argues that after 9/11, the amount of coverage of Islam and Muslims in the UK news media increased dramatically. The Guardian and The Times' coverage of Islam and Muslims from September 12 to October 25, 2001 was similar to their yearly coverage as the preceding year (Poole, 2002 in Mertens \& Smaele, 2016, p. 28). According to several research findings there is a significant difference in the type and volume of coverage connected to national (internal) Islam and international (external/global) Islam. Poole (2016) finds a significant rise in the coverage of Islam and Muslims in the UK news when compared to Islam and Muslims overseas. She claims that, despite the growing coverage of British Muslims, the focus remains on overseas/external Islam. Numerous other studies in the United States, the Netherlands, Germany, and France have found that there is a considerable difference in the sort of coverage given to the 'foreign danger' and the 'domestic other' in the local press. When compared to domestic (national or internal) Islam and Muslims, foreign (external) Islam and Muslims are seen as a 'greater threat' and are considerably more controlled and entrenched in violence (Alsultany, 2012 in Mertens \& Smaele, 2016, p. 64; d'Haenens \& Bink, 2007; Drunen, 2013; Ibrahim, 2010). Similarly, Alazzany (2008) concluded that the news discourse produced by The NYT related to Islam and Muslims was overwhelmed with the themes like, violence, evil, and threat. While covering Islam and Muslims, The NYT focused more on chaotic and violent incidents and intentionally disregarded and overlooked the positive features of the Muslim world. He argued that The NYT purposely produced contrasts and polarization between the internal Muslims and the external Muslims. The newspaper constructed the Muslims in the US as moderate and peace-loving people and the Muslims outside the US were constructed as terrorists, extremists and violent (Alazzany, 2008).

Tsagarousianou (2016) explains the discourses and problematics surrounding the Muslims as a vital European cultural minority. She claims that Islam has been conflated with the religious 
Exploring the discourse of National Islam and Foreign Islam in the Australian press ...

and cultural fanaticism, extremism, and terrorism in the previous two decades. As a result, European Muslims have been painted as enemies of European culture and values, preventing them from fully integrating into European cultures. The situation has sparked debates that define Muslim immigration as a concern and categorize them as a 'manageable' or 'unmanageable' population. Due to its dedication and devotion to Islam and Muslim identity, this 'unmanageable' population is considered as a danger to the European secular identity and social cohesiveness in France, the United Kingdom, and Europe as a whole. In Europe, Muslim identity has been viewed as a weakness that must be remedied by acclimating to the European way of life or by being restricted via various types of exclusion. Islam and Muslims in Europe have been the target of censure and public security as a result of its conceptualization as social instability (Tsagarousianou, 2016, in Mertens \& Smaele, 2016, pp. 4-5).

Considering the detailed and careful review of the literature and keeping in view the findings of the reviewed literature it is evident that the coverage of and reporting on the Muslims within the national boundaries by the international media is considerably different from that of the Muslims outside the boundaries. Media tends to highlight negative things while reporting on and covering the Muslims outside their national boundaries i.e., about the Foreign Islam. On the other hand, on most of the occasions if not always, the same media tends to be supportive towards the Muslims within their national boundaries by highlighting the positive things related to their country fellow Muslims. The researchers around the globe have labelled this phenomenon as a National Islam versus Foreign Islam discourse. So, it seems pertinent to explore whether and to what extent the same phenomenon is existent in the editorial coverage of the Muslims, both internal and external, by the Australian newspapers. The researcher intends to explore, identify and analyse the predominant themes The Age and The Australian have associated with the National Islam and Foreign Islam in their editorial contents during the time period under study.

\section{Research methodology}

\subsection{Data collection and sampling}

Originally this research paper is a part of a larger research endeavour of the researcher wherein overall representation of Islam and Muslims in the two Australian newspapers has been explored and analysed. Employing the 'census sampling' and 'data cleansing' strategies the researcher found 11 editorials from each newspaper under study. All the 22 editorials from both the newspapers were selected using key terms 'Islam' and 'Muslims'. However, for the particular objective of this research paper the researcher selected two editorials from each newspaper which contained the discourse regarding the 'Foreign/External Islam' and/or 'National/Internal Islam'. So, the researcher employed 'purposive sampling' to select two relevant editorials from each newspaper during the time period under study i.e., January 1, 2016 to March 31, 2017. The main objective of this study is to explore and comparatively analyse the predominant themes regarding 'Foreign/External Islam' and 'National/Internal Islam' in the coverage of Islam and Muslims by The Age and The Australian during the time period under study.

\subsection{Data analysis}

To analyse the predominant themes regarding 'Foreign/External Islam' and 'National/Internal 
Islam' in the editorial coverage of Islam and Muslims by The Age and The Australian during the time period under study the researcher has employed the 'ideological square' and the 'lexicalization' techniques proposed by Tuen A. van Dijk (1998) within the paradigm of the Critical Discourse Analysis (CDA). The two approaches have been employed considering their relevance and the suitability with the intended objective of this study.

CDA is an approach that aids the researchers to investigate and examine the dynamics of the 'power, ideology and power' within a text, especially, and in a speech also (Matu and Lubbe, 2007 p.404). Fowler (1991) argues that if we believe that language is a social practice that creates 'reality' and that anything written or said is interpreted through certain ideological position, then CDA advocates critical examining of the newspaper language (Fowler, 1991). The proponents of the CDA argue that the journalists' ideological preferences are not usually apparent in the media content rather they are implicit and latent in the use of various linguistic forms. Such a use of language can only be unpacked through the use of CDA to reach and understand the real meaning of the text (Kuo \& Nakamura, 2005 p. 395). This critical examining of the language and text in the news contents is carried out through the use of various strategies offered by the CDA (Shojaei et al., 2013, p. 860).

According to the CDA model of Tuen A. van Dijk (2001), three components; discourse, cognition, and society, demonstrate that how discourse can mirror 'social ideologies. Discourse here means written text, speech, gestures, and facial expression etc. Cognition refers to social and/or personal understanding, beliefs, and evaluations in the discourse. And society means relationships at local and/or global levels, and global societal structures including group/subgroup relations and political systems (Shojaei, et al., 2013). Van Dijk maintains that the social problems can only be studied in a descriptive, explanatory and especially way by considering all these three components (p. 98).

Van Dijk (1998b) argues that there are no 'standard ways' of doing CDA and ideological analysis of editorials and other forms of text but he proposes few suggestions for doing ideological analyses; (i) Examine the context of the discourse, (ii) analyse groups, power relations and conflicts involved in the discourse, (iii) map out positive and negative opinions about Us and Them, (iv) identify presuppositions and implications, and (v) analyse all formal structures that emphasize/deemphasize the polarized group opinions (Dijk, 1998b, p. 61).

CDA offers a variety of strategies to unpack the hidden meanings in text and speech like; microsociological perspective, Foucauldian perspective and the social cognitive paradigm proposed by Tuen A. van Dijk (Wodak \& Meyer, 2001). In this study the researcher has employed the social cognitive approach proposed by Tuen A. van Dijk (Dijk, 1993; Dijk, 2000a; Dijk, 2000b). According to the Social-Cognitive approach to exercise power the minds are infuenced and manipulated. In an other sense it can be said that there is a direct and deep social-cognitve relation between dominance and the discourse. This is why it is important to examine and analyze the production and reproduction of the texts and the way the texts are received, viewed and understood (Dijk, 1993). Considering the relevance and suitability of this approach the 'lexicalization' and the 'ideological square' strategies have been employed in this study.

\subsection{Ideological square}

Ideology as a concept and as a phenomenon is in the core of the debates under the umbrella of 
Exploring the discourse of National Islam and Foreign Islam in the Australian press ...

the critical discourse analysis (CDA). One can understand the notion of ideology as a belief system or as a set of ideas that people within a society share at collective level in creation of a social representation of various groups (Dijk, 2000a; 2000b). Such an ideology being a function, or an outcome of a socio-cognitive structures can be attained and rejected with the passage of time through a daily discursive process by the people of a society. During this process of attaining and abondoning an ideology a self image of the social identity is created which also results in a political phenomenon called in-group versus out-group polarization (Dijk, 2006).

It means that the ideologies being polarized in nature, especially when they belong to opposite social groups, cause an 'Us' versus 'Them' dichotomy as in the case of racial prejudice discourse regarding immigrants. In this kind of dichotomy a member of a group or a whole group in a society (in-group) portray themselves in positive terms by projecting positive self presentation. And, they use negative and opposing terms for the ones who are out side of their group (out-group and/or Other) while presenting and discussing about 'Them'. Similarly, the members of an in-group tend to highlight the negativities about the members of an out-group with the same passion and concurrence they mitigate their own negative things (Dijk, 1998a; 2006). Van Dijk labels this phenomenon as 'Ideological Square' model. The ideological square approach or phenomenon has four distinctive discursive moves; emphasis on 'our' good things, emphasis on 'their bad things', de-emphasizing 'our' bad things and de-emphasizing 'their' good things (Dijk, 1998a; 1998b).

Van Dijk (2004) argues that there are numerous analytical techniques within the ideological square wherein lexicalization and polarization i.e., the 'Us-Them' categorization are two amongst them. While 'lexicalization' is related to the 'style' the 'polarization' is concerned with the 'meaning' part of the discourse analysis (Dijk, 2004; Philo, 2007).

\subsection{Lexicalization}

During the discursive process of 'ideological polarization' i.e., portraying the in-group (Us) positively and the out-group (Them) negatively the binary positions are employed through the use of various techniques such as the 'lexical choices' or the 'lexical items' (Shojaei et al., 2013, p. 859). The ideological square analysis within the CDA offers 'lexicalization' as a strategy to analyse the use of the lexical items and the lexical choices in a discursive move. Van Dijk (1998) advocates that the 'lexicalization' i.e., the analysis of the 'lexical items' is one of the best methods of analysis in the linguistic and ideological studies. Words are generally or contextually employed and incorporated for the sake of expressing 'opinions' and for making 'value judgments' (p. 31).

So, given the suitability and relevance of the 'Ideological Square' and 'Lexicalization' the researcher has used these two strategies from the paradigm of the CDA to analyse the editorial contents of The Age and The Australian for the sake of determining the predominant themes regarding 'Foreign Islam' and 'National Islam' during January 1, 2016 to March 31, 2017.

\section{Interpretation and analysis}

Following pages contain the interpretation and analysis of the editorial contents of The Age. The editorials have been arranged from latest to the older one. 


\begin{tabular}{|c|c|}
\hline Date & July 11, 2016 \\
\hline Headline & Western voices must swell as IS grip slips \\
\hline
\end{tabular}

Through the lexical choices in this headline such as 'Western Voices', 'must', 'swell', 'grip', and 'slips', the newspaper places 'us' under responsibility to raise voice in favour of Middle East (them) and in solidarity with Muslims (Foreign Islam) when 'they' are being victimized by the 'terrorists' and when the 'IS' is losing its grip in its strongholds. The headline emphasizes dire need of solidarity with the Muslims who are the 'biggest victims' of 'Islamist terrorism'. This is an attempt of creating 'them' within the 'them' by differentiating 'victim Muslims' and 'terrorist Muslims'.

This message is the gist of the whole text and is expanded top to bottom in this editorial. The newspaper identifies 'Muslims' and Islamic nations as victims and vulnerable targets instead of 'enemies' and as less important human beings (Other). Ideologically, 'they' are placed in favourable space where 'they' need 'our' social, political, and economic support. In the lead paragraph, through the use of lexical items The Age comments on 'bombings in the Muslim world' in a balanced and fair way. The newspaper portrays the terrorist attacks stereotypically as 'Islamist terror' but at the same time uses 'slaughter of civilians' for the victims.

In a lexical style, The Age labels the truck bomb in Iraq as 'the bloodiest event' and as an 'atrocity'. In terms of polarization strategy, the 'US led invasion on Iraq' has been compared with this attack and it has been categorized as 'the worst single atrocity'. The counter discourse regarding Muslims is also evident from these comments; the bloodiest event of recent days..., the worst single atrocity since the US-led invasion of 2003.

In the next two paragraphs, the lexical choices such as greater anger, inability to protect citizens, violence, routine fixes, rampant corruption, security threat, and fraudulent equipment, imply that The Age criticizes the US-backed Iraqi government and the role of US in Iraq. Employing a polarization strategy, the newspaper puts Iraqi and the US authorities (us) under responsibility for 'inability to protect citizens' and for the use of 'fake bomb detectors. The counter discourse in which 'our' bad is emphasized is evident from the words like, rampant corruption in Iraq.

In next paragraphs, The Age referring to the attacks in the Middle East and 'slaughter of civilians', emphasizes on 'our' bad. The counter discourse regarding Islam and Muslims is evident from the lexical items such as muted response, slaughter, apolitical show, sympathy, victims, solidarity. Referring to the bombings, the newspaper highlights 'muted response' on 'such slaughter' by West (us) as compared to the response on attacks Paris. In a polarization strategy, comparing the 'highlighting of sectarianism' during the 'Arab Spring', the newspaper criticizes and puts responsibility on 'us'.

Lexically, through the use of words such as muted response, slaughter, Western governments and leaders, apolitical show, sympathy, victims, Western communities, solidarity, repression, message of change, sectarianism, internal divisions, the newspaper places Muslims (Foreign Islam/Them) in the space of sympathy, Westerners (We/Us) in the space of responsibility, and highlights 'corrupt' and dubious role of US authorities (us) in the Middle East. Also, the counter discourse does appear in the form of a comparison between 'our' response to the terrorist attacks in 'our' world and in the Middle East (their). 
Exploring the discourse of National Islam and Foreign Islam in the Australian press ...

In the last paragraph too, in a typical editorial-recommendation style, referring to the delivery of fraudulent equipment, inciting sectarianism, internal divisions, and relatively muted response from the Westerners (us), The Age places responsibility on 'us'. Ideologically, the newspaper emphasizes on 'collectiveness' instead of us versus them divisions, solidarity instead of blame games and on 'smaller US military footprints' in the Middle East.

So, overall, this editorial contains 'foreign Islam' as a predominant discourse and prominent themes linked with the 'foreign Islam' are violence, conflict, sectarianism, and internal divisions.

\begin{tabular}{|c|c|}
\hline Date & April 21, 2016 \\
\hline Headline & Real voices that must be heard \\
\hline
\end{tabular}

In a lexical style, using real voices, must, and be heard, the newspaper offers a counter discourse in terms of the Australian Muslims' representation (National Islam). The 'real voices' are expanded in the text below as 'Muslim voices' and The Age emphasizes that 'they' must be heard. Putting a young Muslim girl Aisha Novakovich and an Eritrean woman in the place of 'actor', the newspaper emphasizes that 'their' voices must be heard. Here, they are neither dehumanized, categorized, stereotyped nor marginalized as an 'exotic other' or as a 'threat' to 'our' security, society, or values. Rather, 'their' voices are shared, 'their' stories are told, 'their' fears are addressed, and 'their' difficulties are highlighted.

This is a very bold declaration, 'The Age agrees', by the newspaper to agree with a statement that admires Osama Bin Laden and his 'abhorrence of Western ideals', and that it must be discussed 'why some people are so enamoured of terrorist groups'. It is a bold assertion by the newspaper especially because the statement comes from a girl with Muslim background. Again, this agreement depicts newspaper's policy 'to respond terrorists collectively and resolutely'. This lead and the subsequent paragraph are full of counter discourse where in a lexical style the newspaper emphasizes 'their lives', 'their fears', and 'their experiences'. The newspaper categorizes 'them' as 'our' friends, neighbours, and colleagues instead of foes, enemies, distant other, and incompatible to 'our' values. Using a polarization strategy, the newspaper emphasizes 'their' good as; it is important to have discussions about why some people are so enamoured of terrorist groups... They may be your neighbours, your friends or colleagues. The newspaper emphasizes 'our' bad as; in their quiet and passionate ways, they warn of potential risks arising from marginalization and disaffection. Also, the declaration, The Age agrees, expresses newspaper's pro-immigration and progressive ideology that favours 'understanding' instead of 'marginalization' and 'disaffection'.

So, this paragraph contains a counter discourse regarding Muslims in Australia (National Islam/Them). Since the discussion here is about 'Muslims in Australia', so the 'national Islam' discourse is predominant.

In next two paragraphs the newspaper has placed Muslims in Australia (National Islam) in a favourable space. For instance, the lexical choices such as practical difficulties, ideological prejudice, outrageous slurs, ignorance, are used to portray Islam and Muslims positively and in a supportive manner. They are presented as being 'prejudiced', 'threatened', and 'vilified' racially and religiously by the Australians (us) in 'ignorance'. To give authority, agency, and formality to its stance The Age quotes survey report findings by the Human Rights Commission 
and Scanlon Foundation. The newspaper categorizes 'their message' as 'overarching' that declares Islam as a religion of peace not violence. Ideologically, the newspaper emphasizes 'our' bad by stressing and highlighting that 'they' (Muslims in Australia) are facing 'practical difficulties', 'stares', 'insult', and 'outrageous slurs' by the Australians (us). So, the predominant discourse in this paragraph is 'National Islam'.

The newspaper, in a lexical style, identifies the 'Muslims voices' as 'emboldened' and 'passionate' and emphasizes that wearing 'hijab' or 'veil' is 'their' democratic right. The choices which the Eritrean woman and Ms Novakovich are shown to have place 'them' in socially, culturally, and religiously favourable space where 'their' rights are highlighted as; her decision to practice them by wearing a hijab or veil was part of her democratic right, and where 'marginalization' or 'discrimination' against them is warned for 'dangerous reaction' as; marginalization or discrimination can feed discontent and rebelliousness....

The newspaper lexically categorizes 'Muslim voices' as 'passion for life', and 'a plea for understanding'. Using the ideologically polarized strategy, The Age places 'them' in a favourable space, emphasizes that 'they' have to compromise 'their' identity to live in Australia. Structurally, the newspaper emphasizes that such a compromise defies 'our' principles of 'common sense', 'decency', 'social cohesion', and 'tolerance'. The newspaper puts 'us' in the responsibility to 'enhance differences', to challenge 'our' assumptions and to stretch 'our' viewpoints. Overall, this paragraph contains 'national Islam' discourse by discussing Muslims and their Islamic identity in Australia.

Using lexical choices, The Age associates 'our' growth and strength with 'practicing mutual understanding', 'relishing diversity', and by 'speaking out against prejudice, intimidation and ignorance. The newspaper identifies Muslims (National Islam/Them) as 'our compatriots' and 'our neighbours'. The newspaper places responsibility on 'us' (The Australians) to speak out against 'prejudice', 'intimidation', and 'ignorance'.

Overall, the newspaper has warned that if the 'marginalization' or 'discrimination' goes unchecked then it can bring back 'dangerous reactions'. The headline and editorial contents underneath it is an example of prominent counter discourse produced by The Age regarding Muslims. The choices the newspaper made from the statements of Ms Aisha and the Eritrean woman, highlights the ideological position as progressive newspaper that speaks in favour of the Muslims in Australia. Ideologically, the newspaper emphasizes on 'their' difficulties and 'our' responsibilities. 'National Islam' is a prominent discourse in this editorial wherein overall themes and direction of Muslims' representation is positive and favourable in this editorial.

Following pages contain the interpretation and analysis of the editorial contents of The Australian. The editorials have been arranged from latest to the older one.

\begin{tabular}{|c|c|}
\hline Date & August 30, 2016 \\
\hline Headline & Burkini ban a step too far \\
\hline
\end{tabular}

The lexical choice in the headline a step too far opted by the newspaper for the 'burkini ban' shows newspaper's policy and ideology about the issue. The 'burkini ban', which is otherwise considered as a violation of 'Westerner/European values' of 'liberty', 'equality', and 'fraternity', has been supported by the newspaper as 'a step or stage beyond what is safe, 
Exploring the discourse of National Islam and Foreign Islam in the Australian press ...

sensible, and desirable'. Ideologically, the binary position taken by The Australian against 'burkini' expresses newspaper's 'rightist' ideological line. Although the newspaper has mentioned, in the text below, that Paris's tribunal has marked burkini ban as an insult to French 'fundamental freedoms' i.e., 'liberty', 'equality', and 'fraternity', but still throughout the text the newspaper has emphasized on the 'security' and 'social threat' attached to the burkini.

In a lexical style The Australian has taken an explicitly binary position about the 'burkini' issue using lexical items such as 'sensitivity' and 'understandable' for the 'ban'. The newspaper suggests 'covering up' instead of the burkini and marks it 'OK' which means 'burkini' is neither 'understandable' nor 'OK'. Lexical choices such as Islamist terrorist attacks, not surprising, overt displays, fundamentalist Islamic practices, insecurity, even outrage, explicit connection, burkini and terrorism, opted by the newspaper to comment on the issue show negative opinion of the newspaper about the burkini. The ban has been justified and burkini has been attached with 'terrorism' and 'insecurity'. While the lexical items such as denounces, enslaving, patriarchal religion, incompatible, French values, used by the newspaper give an impression of dehumanizing Islamic and Muslim.

In terms of the polarization strategy, the newspaper emphasizes 'our' good and 'their' bad. The burkini and 'Islamic practices', in a collectivism and stereotypical style, have been labelled as 'fundamentalist' and have been associated with 'insecurity' and 'outrage'. Islam and Muslims have been represented as misogynistic, inferior and backward. Such a discourse is available in the form of comments such as French sensitivity is understandable but covering up is OK... Prime Minister Manuel Valls denounces the burkini as a means of "enslaving" women to a patriarchal religion, arguing it is incompatible with French values. The lexical choices such as far cry, swimsuit's beginnings, medieval obscurantism, so-called Islamic caliphate, portrays a 'backward' image of Islam. The rest of the text in this paragraph contains an impression that the 'burkini' is far different from the swimsuits worn by people in modern ages. In terms of ideological square, 'their' bad has been emphasized by portraying 'them' associated with 'medieval obscurantism'.

Overall, in this editorial Islam and Muslims have been portrayed as 'backward', 'misogynists', 'exotic', 'incompatible', and 'inferior'. Islam and Muslims have been associated with terrorism, insecurity, outrage, fundamentalism, and ire. Since the overall discussion is devoted to 'burkini ban' in France, so the editorial falls in the discourse category of 'foreign Islam'. Prominent themes associated with 'foreign Islam' are collectivism, violence, and women underrepresentation. Overall, Islam and Muslims have been portrayed negatively.

\begin{tabular}{|c|c|}
\hline Date & February 25, 2016 \\
\hline Headline & Islamic schools at a crossroads \\
\hline
\end{tabular}

According to Oxford dictionary, 'crossroads' means an important point or stage in one's life/development where she/he has to decide which way to go (Oxford, 2005, p. 367). Placing 'Islamic schools' (them/out-group) at a 'crossroads', The Australian places 'them' in a 'perplexed' situation. The 'crossroads' or the 'perplexed' situation is elaborated in the underneath text wherein 'they' are portrayed as the only schools with 'financial mismanagements'. The 'Islamic' nature of the schools makes 'them' different and 'not fit for a responsible oversight role'. So, the headline represents newspaper's opinion in a clearly lexical and polarized form. 
Using lexical items such as government funding, must, scrutiny, the newspaper imposes 'our' authority and the use of 'Australia's 39 Islamic schools' separates 'Islamic schools' (National Islam) and collectivize 'them' on the basis of religious identity. So, the focus is on 'difference' and the difference is 'religious' from 'all Australian schools'. In terms of 'ideological square' the newspaper mitigates 'their' good by not appreciating the 'enrolment increase'. The emphasis on the 'Islamic' nature (religious identity) of the schools and 'their' comparison to 'all Australian schools', implies the 'othering' approach by the newspaper while reporting Muslims in Australia.

The newspaper uses evaluative terms in such as small, but growing arm, Islamic schools, their fair share, which imply the emphasis on 'difference'. While the lexical items such as nation's education system and taxpayers' support, separate 'them' from 'nation's education system with the emphasis on 'their' Islamic identity and the 'taxpayers' support' implies that 'they' are an economic burden on 'us'. In terms of the 'ideological square', 'our' good has been emphasized through the comment; Islamic schools receive their fair share of taxpayers' support. On the other hand, 'their' bad is emphasized by portraying 'them' as receivers of the money and that the taxpayers are only the 'Australians' (we). In the comment, as a small but growing arm of the nation's education system, the newspaper separates 'them' from 'nation's education system' (us) and emphasizes on evaluative term 'small but growing' while reporting 'them'. Despite the fact the 'Islamic schools' are highly enrolled schools, still the newspaper portrays them as 'small but growing'. On the other hand, when it comes to the taxpayers' money, the newspaper stresses that 'they' are receiving 'their fair share'.

Lexical choices opted by the newspaper to comment on the issue, such as investigative reporting, cut commonwealth funding, nation's largest Islamic school, revealed, financial mismanagement, could close, serious problems, uncovered, put them on notice, portray a negative image of the 'Islamic schools'. The use of 'five years of investigation', and 'uncover' implies that the 'problem' is now new or simple but it's a long and complicated problem which has been 'uncovered' now. The newspaper reports that there are 39 Islamic schools in Australia and 'mismanagement' has been 'uncovered' in fewer schools, but rest of the schools have been labelled with 'serious problems' in a 'collectivized' way.

In terms of 'ideological square', the newspaper emphasizes on 'their' bad by stressing on their 'mismanagement' as; Education Minister Simon Birmingham has cut commonwealth funding to the nation's largest Islamic school after a Deloitte audit report revealed financial mismanagement by the Australian Federation of Islamic Councils. Malek Fahd Islamic School at Greenacre in Sydney's southwest, with 2400 students, could close in April. On the other hand, 'our' bad is mitigated by stressing on the angle that the 'serious problems' which were 'uncovered' at the schools made 'authorities' to put 'them on notice' as; After serious problems were uncovered at schools in Brisbane, Canberra, Melbourne, Adelaide and Perth, the minister had no choice but to put them on notice that their funding also would be cut if they didn't show cause why they should remain open. The use of 'investigative reporting' and the designation along with the name of the minister formalizes the 'seriousness' of the issue and emphasizes 'our' authority. In this comment, the newspaper emphasizes 'their' bad, mitigates 'our' bad, and portrays 'them' as liability.

So, overall, the out-group i.e., Islamic schools (National Islam) has been portrayed as problematic and subordinate that needs to be 'scrutinized'. On the other hand, the in-group has 
Exploring the discourse of National Islam and Foreign Islam in the Australian press ...

been portrayed as an 'authority', 'superior', and the one who bears the economic burden.

In terms of lexicalization and ideological square, next paragraph of the editorial is the most polarized, biased, and asserting 'their' bad. In the first sentence, the 'Islamic schools' (they) have been compared with the Christian, Jewish and other non-government schools (us). The newspaper uses 'well run' and 'accountable' for 'our' schools and Muslims 'educational house' has been asked to 'put in order', failing to which 'they are likely to lose their schools'. The impression of 'their' bad is enhanced through evaluative terms; public purse, disadvantaged, non-English speaking backgrounds, which portray 'them' as an 'economic burden'. Using lexical items such as no Muslim equivalent, Islamic schools' problems, not fit for a responsible oversight role, the newspaper compares 'Islamic schools' (their/them) with 'the Catholic education system' (our/us) and presupposes AFIC the 'cause' of 'their' problems and as 'not fit for a responsible oversight role'. In next part of the paragraph, The Australian using lexical items considers the 'stand down' of the 'former board' a 'good sign' because of the parents, students and alumni stood up to their leaders. The newspaper's emphasis on 'their' bad also evident from the presupposition that the 'leaders fail to grasp' that the schools 'must be transparent and professional in handling taxpayers' money'.

In terms of ideological square, the divisions and comparisons between in-group and out-group, wherein 'their' bad and 'our' good is emphasized, are evident from the comments such as with Christian, Jewish and other non-government schools that are well run and accountable, Muslim leaders and communities need to put their educational house in order or they are likely to lose their schools... While there is no Muslim equivalent of the Catholic education system.

Overall, in this editorial Muslims have been portrayed negatively as an out-group. The outgroup has been portrayed as inferior to 'us', subordinate to 'us', incompetent, not fit for responsible oversight role, and problematic 'other'. Despite the fact that 'Islamic schools' are highly enrolled schools in the country the newspaper portrays 'their' negative image and emphasizes 'their' bad. The Islamic schools have been excluded from 'us' and have been presented as below par as compared to 'our' schools. The newspaper emphasizes 'our' authority, 'their' subordinate nature, 'our' professionalism, and 'their' mismanagement. Since the discussion and opinion in this editorial is about Islam and Muslims within Australia, so the editorial falls in the 'national Islam' discourse category. Prominent themes associated with national Islam are conflict and collectivism.

\section{Conclusion}

Bearing in the mind the work of Tsagarousianou (2016) and Mertens (2016), the researcher explored, identified and investigated the thematic variations in the coverage of Islam and Muslims within Australia (National/Internal Islam) and beyond Australia (Foreign/External Islam). The results of this study have revealed that while covering 'Foreign Islam,' both the selected newspapers have emphasized on and highlighted the 'conflict', 'violence' and 'collectivism' related to Islam and Muslims. Additionally, The Australian highlighted the 'women underrepresentation' also. The Age, on the other hand, concentrated on 'victimization' and 'prejudice' faced by the Muslims in Australia. This newspaper has emphasized on the importance of 'understanding' 'harmony' and 'cohesion'. As an important finding, The Australian constructed the 'National Islam' with the same themes it conflated with the 'Foreign Islam' namely 'violence', 'collectivism', 'conflict', and 'women underrepresentation'. 
As the earlier research findings have shown, there is a significant and considerable difference in international reporting on the National Islam and the Foreign Islam (Mertens, 2016; Baker, et al., 2013; Drunen, 2013; Ibrahim, 2010; d'Haenens \& Bink, 2007; Richardson, 2004) the findings of this research attempt show that the same tendency is visible and noticeable in the Australian press. However, in the Australian press, there is a clear distinction: The Australian conflated both the 'Foreign Islam' and the 'National Islam' with the same negative elements, whilst The Age associated supporting aspects with 'National Islam'. So, according to the research findings, both the 'National Islam' and the 'Foreign Islam' have been given significantly negative and unfavourable coverage, with a focus on violence, confrontation, collectivism, and women's underrepresentation.

The findings of this study are almost in the same line as pointed out by previous researchers in the US, UK and in other European countries. However, the shock is that the stereotyping, collectivism and negative portrayal of Muslims, who are a considerably huge minority population in Australia, by the mainstream Australian press would result in the increase of racial attacks, discrimination, prejudice and marginalization of the Muslims. Muslims who play an important economic role in the Australian society would face violation of human rights. They would be excluded from the mainstream society. And, if such trends are carried on and encouraged by the national media then one can fear that the international image of Australia as a 'multicultural society' and as a 'migrant-friendly' country would be at stake. No doubt there is a ray of hope in terms of the news coverage given by the media like The Age which attempts to emphasize on the harmony, understanding and co-existence. However, the fruits of such attempts are subsided with the explicit negative coverage given by a comparatively huge newspaper The Australian.

\section{References}

Akbarzadeh, S., \& Smith, B. (2005). The representation of Islam and Muslims in the media. School of Political and Social Inquiry, 4.

Alazzany, M. A. O. A. (2008). A critical discourse analysis of the representation of Islam and Muslims following the 9/11 events as reported in the New York Times (Doctoral dissertation, Universiti Putra Malaysia).

Alharbi, A. (2017). Corpus Linguistic Analysis of the Representation of 'IAM'in the Australian Press before and after 9/11. Language Discourse \& Society, 107.

Alsultany, E. (2012). Arabs and Muslims in the Media: Race and representation after 9/11. In: S. Mertens \& H. D. Smaele, eds. Representations of Islam in the News: a crosscultural analysis. Lexington Books, p. 64.

Anon., (2007). Issues Deliberation Australia/America. [Online] Available at: IDa, (2007). Muslims and Non-Muslims in Australiahttp://www.ida.org.au/UserFiles/File/AUSTRALIA\%20DELIBERATES\% 20-\%20FINAL\%20REPORT\%20-\%20CHAPTER\%202\%

Anon. (2016). Australian Bureau of Statistics. [Online] http://www.abs.gov.au/AUSSTATS/abs@.nsf/mediareleasesbyReleaseDate/7E65A 144540551D7CA258148000E2B85?OpenDocument

Baker, P., Gabrielatos, C., \& McEnery, T. (2013). Discourse analysis and media attitudes: The representation of Islam in the British press. Cambridge University. 
Exploring the discourse of National Islam and Foreign Islam in the Australian press ...

d'Haenens, L., \& Bink, S. (2007). Islam in the Dutch press: With special attention to the Algemeen Dagblad. Media, Culture \& Society, 29(1), 135-149. https://journals.sagepub.com/doi/abs/10.1177/0163443706072002? journalCode=mc $\underline{\mathrm{sa}}$

Drunen, V. A. S. (2013). Media Coverage of Muslims: the foreign threat versus the domestic other. Etmaal van de communicatiewetenschap, Rotterdam, the Netherlands, February, 7-8.

Ghauri, M. J., \& Umber, S. (2019). A Critical Discourse Analysis of the National Islam and Foreign Islam in the Australian Press. Islamic Studies, 58(3), 403. https://www.jstor.org/stable/26899430

Ibrahim, D. (2010). The framing of Islam on network news following the September 11th attacks. International Communication Gazette, 72(1), 111-125. https://doi.org/10.1177/1748048509350342

Kuo, S. H., \& Nakamura, M. (2005). Translation or transformation? A case study of language and ideology in the Taiwanese press. Discourse \& Society, 16(3), 393-417. https://doi.org/10.1177/0957926505051172

Matu, P. M., \& Lubbe, H. J. (2007). Investigating language and ideology: A presentation of the ideological square and transitivity in the editorials of three Kenyan newspapers. Journal of Language and Politics, 6(3), 401-418. https://doi.org/10.1075/jlp.6.3.07mat

Mertens, S. (2016). European media coverage of Islam in a globalizing world. Representations of Islam in the News: a cross-cultural analysis, 59-73.

Mertens, S. \& Smaele, H. D., (2016). In: S. Mertens \& H. D. Smaele, eds. Representations of Islam in the News: a cross-cultural analysis. Maryland: Lexington Books.

Munro, I. (2006). Portrayal of Muslims 'tainted by racism'. Retrieved march, 17, 2015.

Nurullah, A. S. (2010). Portrayal of Muslims in the media:"24" and the 'Othering'process. International Journal of Human Sciences, 7(1), 1020-1046. https://www.acarindex.com/dosyalar/makale/acarindex-1423936688.pdf

Philo, G. (2007). Can discourse analysis successfully explain the content of media and journalistic practice?. Journalism studies, $8(2), \quad$ 175-196. https://doi.org/10.1080/14616700601148804

Poole, E. (2002). Reporting Islam: Media representations of British Muslims. In: S. Mertens \& H. D. Smaele, eds. Representations of Islam in the News: a cross-cultural analysis. Maryland-USA: Lexington Books, pp. 21-36.

Poole, E. (2016). The United Kingdom's Reporting of Islam and Muslims; Reviewing the Field. In: S. Mertens \& H. D. Smaele, eds. Representations of Islam in the News: a crosscultural analysis. Maryland-USA: Lexington Books, pp. 21-36.

Quayle, A., \& Sonn, C. C. (2009). The construction of Muslims as "Other" in mainstream Australia's print media: An analysis of discourse. The Australian community psychologist, 21(1), 8-23.

Rane, H. (2000). Australian press coverage of Islam. Unpublished master's thesis). Bond University, Australia.

Rane, H. (2008). Knowing One Another: An Antidote for Mass Media Islam. Brisbane: Griffith Islamic Research Unit.

Richardson, J. E. (2004). (Mis) representing Islam: The racism and rhetoric of British broadsheet newspapers (Vol. 9). John Benjamins Publishing.

Safi, M., \& Evershed, N. (2015). Three-quarters of Muslim Australians feel they are unfairly targeted by terror laws, study reveals. The Guardian. 
Said, E. W. (1997). Covering Islam: How the Media and the Experts Determine How We See the Rest of the World. London: Vintage.

Shojaei, A., Youssefi, K., \& Hosseini, H. S. (2013). A CDA Approach to the Biased Interpretation and Representation of Ideologically Conflicting Ideas in Western Printed Media. Journal of Language Teaching \& Research, 4(4). https://doi.org/10.4304/jltr.4.4.858-868

Susskind, R. (2002). Representation of Muslims in the Australian print media. School of Applied Communication.

Tolj, B. (2017). Number of Muslims in Australia soars Census 2016. Daily Mail.

Tsagarousianou, R. (2016). Muslims in Public and Media Discourse in Western Europe: The Reproduction of Aporia and Exclusion. In: S. Mertens \& H. D. Smaele, eds. Representations of Islam in the News: a cross-cultural analysis. Maryland-USA: Lexington Books, pp. 3-20.

Van Dijk, T. A. (1993). Principles of critical discourse analysis. Discourse \& society, 4(2), 249-283. https://doi.org/10.1177/0957926593004002006

Van Dijk, T. A. (1998a). Ideology: A multidisciplinary approach. Sage.

Van Dijk, T. A. (1998a). Opinions and Ideologies in the Press. In: A. Bell \& P. Garrett, eds. Approaches to Media Discourse. Oxford: Blackwell, pp. 21-63.

Van Dijk, T. A. (2000a). Ideology and discourse: A multidisciplinary introduction. Pompeu Fabra University, Barcelona, 1025-1034.

Van Dijk, T. A. (2000b). New (s) racism: A discourse analytical approach. Ethnic minorities and the media, 37, 33-49. http://www.discourses.org/OldArticles/New\%28s\%29\%20racism\%20\%20A\%20discourse\%20analytical\%20approach.pdf

Van Dijk, T. A. (2004). Politics, ideology and discourse. In: K. B. (Ed.), ed. Encyclopedia of Language and Linguistics. Oxford, UK: Elsevier, pp. 728-740.

Van Dijk, T. A. (2006). Ideology and discourse analysis. Journal of political ideologies, 11(2), 115-140. https://doi.org/10.1080/13569310600687908

Wodak, R., \& Meyer, M. (Eds.). (2015). Methods of critical discourse studies. Sage.

Yasmeen, S. (2007). Muslim women as citizens in Australia: Diverse notions and practices. Australian Journal of Social Issues, 42(1), 41-54. https://doi.org/10.1002/j.1839-4655.2007.tb00038.x 